\title{
Peace Perceptions Of Prospective Teachers For Promoting Peace Activities For School Settings In Pakistan
}

\author{
Muhammad Imran Yousuf, PMAS Arid Agriculture University, Pakistan \\ Muhammad Sarwar, University of Worcester, UK \\ Gareth Dart, University of Worcester, UK \\ Muhmmad Naseer-ud-Din, KUST, Pakistan
}

\begin{abstract}
Peace has been recognized as a matter of education and to be promoted at the initial level. The present study attempts to generate a profile of activities toward peace education among prospective teachers. The Nominal Group Technique (NGT) was used by selecting fifteen prospective teachers as a Nominal Group (NG). NGT was applied under a sequence of stages (idea generating, selection, listing, clarification, ranking and consensus stages). Results generated from the NGT were organized into three categories of student-related activities, teacher-focused activities, and administration and community-related activities. Participants' preferences were higher for activities that included individual practical participation. Participation in the Action Research process was ranked at the bottom. Tentative conclusions are drawn with regard to teacher education and peace studies.
\end{abstract}

Keywords: Peace activities, Peace education, Nominal Group Technique, Peace perceptions, School setting

\section{INTRODUCTION}

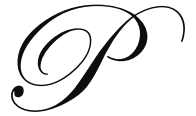

eace education is educating all people for peace to satisfy their physical and social needs through individual and group action at the micro (interpersonal) and macro (local, national, and global inter group) levels. Educating all people for peace is only possible by developing altruism, friendship, beneficial relationships and by working cooperatively with others. Peace cannot be secured entirely by commercial interests, military alliances, general disarmament, or mutual treaties; rather, the spirit for peace needs to exist in the minds and will of the people and so it is necessarily a matter of education (Sica, 1981).

Hicks (1985) defines peace education as activities that develop the knowledge, skills and attitudes needed to explore concepts of peace, enquire into the obstacles to peace both in individuals and societies, to resolve conflicts in a just and non-violent way, and to study ways of constructing just and sustainable alternative futures.

Galtung (1995) sees 'peace studies' as evolving from a focus on research and building knowledge with an emphasis on skill-building. Insight into the roots of violence must be balanced with work on devising ways to overcome, reduce and prevent violence. For Galtung, the reforming of cultures and social structures that are antithetical to peace is the essential challenge. Overall, Peace Studies covers the content areas of peace education, including values underlying peace, violence and war, non-violence, economic and social justice, environmental protection, and participation (Regan, 1993).

Peace education is most effective when the skills of peace and conflict resolution are learned actively and are modeled by the school environment in which pupils are taught (Baldo and Furniss, 1998). Educational programs have the potential to make strides at achieving peace through various educational efforts and processes in formal, non-formal, and informal education. Formal education in schools, universities and other channels, according to Ginsburg, et. al. (1995) can function toward educating students for peace. Teachers have been found able to institute 
curriculum, pedagogy, and evaluation procedures to encourage the development of peace. For informal education, (which can be described as an organized systematic of educational activity carried on outside the framework of the formal system to selected types of learning to particular subgroups in the population, adults as well as children) family socialization, mass media and organized sports activities can play a positive role for conflict resolution and establish cooperation, altruism, friendship, and beneficial relations. Various international, national, and local Non Governmental Organizations (NGOs) have been successful in developing non-formal programs to promote peace education among masses (Ginsburg, et. al. 1995).

If education is one of the more important defenses against human catastrophe, then arguably peace education is the soul of education that can create the shield for human survival on the planet earth. It is assumed that peace can be installed in human minds as an antidote to war. The emphasis here is the knowledge component of peace education, defining peace as a multi-disciplinary academic and moral quest for solutions to the problems of war and injustice with the consequential development of institutions and movements that will contribute to a peace that is based on justice and reconciliation (COPRED, 1986).

Another perspective of peace education considers it as a global term applying to all educational endeavors and activities which take, as their focus, the promotion of knowledge of peace and of peace-building. It promotes in the learners, the attitudes of tolerance and empathy, as well as skills in cooperation, conflict avoidance and conflict resolution so that learners will have the capacity and motivation, individually and collectively, to live in peace with others (Cremin, 1993).

One of the basic activities of Peace Education is to introduce qualitative social research through which the personal skills of teachers and students could be improved, as well as the organization of the school. The opportunity to be an observer, as well as an actor, in an educational situation stimulates the sensitivity for social interaction and supports the development for the implementation of peace education among the teachers. The assumption that peace education must combine knowledge, skills and attitudes is perhaps the dominant one in the field at this time. For this, peace education is considered as a process that prepares young people for global responsibility, enables them to understand the nature and implications of global interdependence, and helps them to accept responsibility to work for a just, peaceful and viable global community (Reardon, 1988).

\section{OBJECTIVES OF THE STUDY}

The objectives of the study were as:

- To investigate the peace perceptions of prospective teachers

- $\quad$ To draw the preferences of peace promotion activities within the school setting

\section{METHODOLOGY}

\section{Sample}

The sample consisted of fifteen prospective teachers to act as the Nominal Group (NG), who were full-time teachers from different schools in the Provincial Department of Education at Rawalpindi, Pakistan and were part time students at the Division of Continuing Education, Pir Mehr Ali Shah Arid Agriculture University, Rawalpindi, Pakistan. The members of group were given seats far apart from each other so that there would be no consultations between them. This would give each participant a chance to think of the desired answer of the question.

\section{Research Technique}

The data was collected by using Nominal Group Technique (NGT). The nominal group technique is a participative exercise, which can be used with small groups to obtain an agreement and consensus regarding a particular aspect. The nominal group technique is an effective way to make pooled judgments or decisions in groups which meet face-to-face (Delbecq et al., 1975). Different stages were designed in applying NGT. 
1. Idea Generating Stage: the first was Idea Generating Stage, in which participants were asked to write as many ideas as possible in response to the question. They were also told that these ideas need not be personally believed by them to be true or untrue. They were asked to put down all ideas, which they thought were influential ideas for topic.

2. Selection Stage: during Selection Stage, participants were asked to refine their ideas and select two ideas, which they thought the best strictly in terms of the question that was asked. They were given an opportunity to pick the next two ideas and were told to keep the other ideas in reserve.

3. Listing Stage: in Listing Stage, each participant was given a chance to give the best and to describe it in detail. The idea given by each member was recorded on a flip chart. If a participant's best idea was already given by another one, that person was asked to choose the next best or, failing that, a reserve idea.

4. Clarification Stage: The Clarification Stage was organized in such a way that if two or more ideas given by participants were similar in nature, the researchers removed the duplication from the list. In this exercise, two ideas that were similar were merged into one. Participants were given a chance to give their next best choice. Another seven more ideas were added by the NG. From the second list, two ideas were sufficiently similar and they were also merged into one idea. Participants were given a chance to give alternative ideas if they wanted. The ideas were sequentially numbered on the flip chart.

5. Ranking Stage: then in Ranking Stage, the participants were asked to rank six ideas of each category independently.

6. Consensus Stage: finally, in Consensus Stage, the ranking were collected by the researchers and summed up for each item to obtain an overall ranking for that item. This gave an average ranking for all the items.

\section{RESULTS}

Results generated from NGT were organized into three categories of student related activities; teacher focused activities; and administration activities and community related activities.

1. Student Related Activities: With regard to student focused activities,

- Top priority was given for the activity of displaying information of culture based matters (mean ranking 1.8).

- Second ranking was reserved to write slogans \& poems (mean ranking 2.8).

- Third preference was granted to the activity of collecting and writing down the proverbs \& sayings about the peace theme (mean ranking 3.3).

- The activity of studying lives of peace makers was placed at fourth rank (mean ranking 3.4) by the NG.

- Fifth ranking was available for the activity of taking oath to evangelize the value of peace (mean ranking 3.9).

- Last priority was found for participation in Action Research processes (mean ranking 5.2).

2. Teacher Related Activities: One of the basic activities of Peace Education is to introduce qualitative social research through which the personal skills of teachers and students could be improved as well as the organization of the school.

- The ranking obtained from the second category about the teacher focused activities, indicates that maximum number of participants wanted the teachers to guide their students to record their thought, poems or prayers at the theme of peace education for promotion of peace education among students (mean ranking 1.6).

- Second preference was granted to rationalize the concept of conflict and the way to avoid it. 
- Third ranking was given to activity of dealing with unexpected situations through Action research (mean ranking 2.6).

- Fourth rank was available to the activity of providing proper knowledge to understand global realities so that it may set good relation among each other (mean ranking 3.9).

- Whereas fifth ranking as assigned to the activity to integrate peace education with moral education and religious education (mean ranking 4.6).

- Team teaching to evaluate one's own way of teaching as an activity for peace education propagation was not given much preferences; hence found at last ranking.

3. Administration \& Community related Activities: It is peace education which inculcates and builds love, friendship and international understanding. We intend to teach the young minds valuable contribution towards peaceful society. The society which upholds the values of equality, solidarity, freedom, democratic inclination, tolerance, care and respect for others and willingness to change. If we intend to create a peaceful society we must renew our educational society, which has no scope for inculcating the human values. The third category of results emerged from NGT was ranking the peace education activities related to administration and community.

- $\quad$ First preference was granted to the activity of arranging sports and games (mean ranking 1.7).

- Second preference was for the activity of organizing scouts and Girl Guide programmes (mean ranking 2.9).

- Third rank was available for the activity of internship based activity.

- Whereas fourth rank was granted to peace march (mean ranking 3.8).

- The fifth ranking was made to arranging of weekly sessions of morality (mean ranking 3.9).

- The last ranking was made for the activity of participation in out of school events.

\section{DISCUSSION}

Peace is often construed as a national/international phenomena, far from our daily life, and that global peace can only be achieved if each country is settled and at peace. However, the peace and happiness of each country can only be achieved if every citizen is at peace. Pakistan is currently a prime example of a country that lacks peace; its culture is fragmented by differences of class, economics, politics, ideologies, religion, language, territory, caste and color. Differences can lead to imbalance, dissension and discord. Investigation reveals that the cause of much unrest comes from individual people's own mental unrest.

Admitting these factors, we must train prospective teachers for peace and must create a positive attitude toward peace such that it reflects it into young minds. It is important to see past issues and to go beyond immediate controversies to locate the values underlying them and how conflicts between differing values might hinder progress toward peace.

The ranking for student-related activities to promote peace education within the school setting makes it clear that preferences of Nominal Group of prospective teachers favored students working for peace activities in which individual participation was desired at a practical level; so collection of culture-based information, writing their own poems and then collection of proverbs, ranked as high priority. In order to resolve and analyze initial problems in a classroom setting, the conduct of action research on the part of the students and the teachers is very much required. However, the findings of this study indicate that the activity to participate in Action Research process was ranked at the bottom by the respondents (mean ranking 5.2); this may be due to the fact that research culture is not common in classroom settings in Pakistan.

Peace is not sold in the market; it is personal as well as universal. Today, society is awakening to the reality of lending a hand, which is a good sign of peace. The caring of people as a sign of hope must be encouraged. All of us have to put our shoulders to the wheel if we want a better tomorrow. Whether in a family, a class, staff, a team, or a country, it is necessary to have a homey atmosphere - an atmosphere that is conducive to thinking about the 
meeting of minds and heads. If there is no cooperation then each one will seek faults in others and no progress will take place.

Peace Week events could be planned early by a core committee of teachers, parents, students, and volunteers. One person could plan a peace assembly for sharing events planned by different grades or classrooms. Another could coordinate a peace poster sharing session. Rather than holding a competitive contest with awards and prizes for only a few, schools should embrace all students as members of the school community, each contributing a special talent or expertise. This research in peace education can be useful in various ways to provide much opportunity for students and teachers to promote the concepts of pace in universal extent in their normal teaching/learning process.

\section{AUTHOR INFORMATION}

Dr. Muhammad Imran Yousuf is working as Assistant Professor in Division of Continuing Education, Pir Mehr Ali Shah Arid Agriculture University, Rawalpindi, Pakistan. He did his M.Phil. in Teacher Education from Allama Iqbal Open University, Pakistan and Ph.D. in Education from University Institute of Education and Research, UAAR, Pakistan. E-mail: dr.imran@uaar.edu.pk

Dr. Muhammad Sarwar is presently working as post-doctoral fellow in the Institute of Education, University of Worcester, UK whereas he is Assistant Professor in Department of Education, University of Sargodha, Pakistan. He did his M.Phil. in Education from Allama Iqbal Open University, Pakistan and Ph.D. in Education from University Institute of Education and Research, UAAR, Pakistan. E-mail: m.sarwar@worc.ac.uk

Gareth Dart is working Educational studies course leader in the institute of education, university of Worcester, UK. His major area of interest is international studies in education, comparative education and inclusive education. Ph: 0044-1905-542149 Email: g.dart@worc.ac.uk

Dr. Muhammad Naseer-ud-Din is working as Assistant Professor in Department of Education, Kohat University of Science and Technology, Kohat, Pakistan.. He did his Ph.D. in Education from University Institute of Education and Research, UAAR, Pakistan. E-mail: naseer_khanpk2000@yahoo.com

\section{REFERENCES}

1. Baldo, M., and Furniss, E., (1998). 'Integrating life skills into the primary curriculum'. New York, UNICEF.

2. COPRED (1986). 'Report on the Juniata Process' Consortium on Peace Research, Education and Development, Peace Chronicle, December 1986.

3. Cremin, P., (1993). 'Promoting education for peace.' In Cremin, P., ed., 1993, Education for Peace. Educational Studies Association of Ireland and the Irish Peace Institute.

4. Delbecq, A.L., Van de Ven, A.H. and Gustafson, D.H. Group Techniques for Program Planning: A Guide to Nominal Group and Delphi Processes. Glenview, IL: Scott, Foresman \& Company, 1975.

5. El-Zahhar, N. (1995). Peace Education: A Model for Establishing Positive Peace, Paper presented at the United Nations Symposium on "Arms Control, Disarmament, and Peace in the Middle East" NGOs Committee on Disarmament, The UN, September 21, 1995, New York, USA.

6. Galtung, J., and Ikeda, D., (1995). Choose peace. London, Pluto Press.

7. Hicks, D., 1985. Education for peace: issues, dilemmas and alternatives. Lancaster: St. Martin's College.

8. Reardon, B., ed., (1988). Educating for global responsibility: Teacher-designed curricula for peace education, K-12. New York: Teachers College Press, Columbia University.

9. Regan, C., (1993). 'Peace education: a global imperative'. In Cremin, P., ed., 1993, Education for Peace. Educational Studies Association of Ireland and the Irish Peace Institute.

10. Sica, M. (1981). Footsteps of the Founder - Lord Robert Baden-Powell, Editrice Ancora, Milano, Italy. 
NOTES 